\title{
Research on Stress and Deformation Characteristics Pile Foundation System to Support Roof
}

\author{
Fei Xiao, a ,Jun Han ${ }^{1, b}$,Wan Zhang ${ }^{1, c}$ \\ 1. Jiangsu Jianyan Quality Appraisal of Construction Engineering Co.Ltd., Nanjing 211899, P.R. China \\ azny2008@163.com, b239583341@qq.com, c3649525@163.com
}

\begin{abstract}
Keywords: karst roof, pile foundation, stability, numerical simulation, flac.
Abstract. Pile foundation is often used in the construction of communication tower in the karst region. Stability of pile foundation to support roof is related safety of the superstructure equipment. No deep special study on stability of pile foundation in karst region has been reported yet. Reliability of evaluation results by traditional qualitative analysis method and semi-quantitative analysis method needs further discussions. Studying stress and deformation characteristics of pile foundation system to support roof deeply has important theoretical and practical significance to improve understanding of the problem. In this study, effects of pile foundation for the communication tower in a karst region on cavity roof of underlying karst were discussed by FLAC $^{3 \mathrm{~d}}$ numerical simulation. Stress and deformation characteristics of roof under loading of pile foundation were analyzed. The relationships between depth of pile bottom and settlement of pile foundation and displacement of roof were discussed. Research conclusions can offer certain references to design, construction and operation monitoring of the project, as well as some references for similar engineering constructions.
\end{abstract}

\section{Introduction}

During infrastructure construction, disasters caused by karst geology occur frequently in engineering construction and operations, thus resulting in huge property damage ${ }^{[1]}$. Particularly, disasters will influence engineering design, construction and operation significantly in large karsts which are developed in shallow underground places. Small karsts can be treated by filling stones or pile foundation connection. Large karst is often avoided during architectural construction. Nevertheless, karst region couldn't be avoided in construction engineering of communication tower due to influences of radiation region and advantageous landform control.

To ensure stability of tower structure under wind load, tower structure not only requires high bearing capacity to the foundation system, but also has to meet high uplift resistance. The advantages of pile foundation to make full use of geological conditions and load conditions of multiple formations are developed fully. Therefore, pile foundation is the first choice of engineering construction in karst region. In traditional construction, piles are paved through the karst cave to act on the underlying bed rock, so that the adverse impacts of karst cave on pile foundation can be reduced significantly, protecting stability of the foundation ${ }^{[2]}$. However, it claims high cost for piles to run through the cave in some construction regions with highly karst development due to the difficulty construction and large karst bury depth. It has to consider placing pile foundation at the upper roof of $\mathrm{karst}^{[3-8]}$. Under this circumstance, a bearing system composed of pile foundation and karst roof is formed. Analyzing stress conditions of this system is very important to safety of design construction.

In this study, a three-dimensional finite difference program FLAC $^{3 \mathrm{~d}}$ was used. Effects of file foundation for a communication tower in a karst region on the karst cave roof were discussed by a simple three-dimensional pile foundation-karst model. Stress and deformation characteristics of roof under pile foundation load were studied. The relationships between depth of pile bottom and settlement 
of pile foundation and displacement of roof were analyzed, aiming to increase understanding on the system structure.

\section{Geological conditions of the study area}

The study is in Guizhou Province, China. It is a low mountains and hilly district. The communication tower is planned to be built at the top of hilly slope which is formed by corrosion. Due to historical corrosion, abundant karst caves have been developed in mountains below the tower. According to drilling results, limestone, carbonaceous limestone and deluvial silty clay as well as pebble bed of the quaternary system are main lithologies close to the tower region. There are rich surface water reserves at the tower location and surrounding areas. Groundwater is mainly supplied by fissure water of the quaternary system. Neither surface water nor groundwater can cause corrosion to concrete.

The underlying moderate silky weathered rocks at foundation can be used as the bearing stratum of tower pile foundation because of the high strength, high development thickness and uniform and stable development. According to drilling and geophysical prospecting, there's one middle-sized karst cave in the rock stratum below the pile foundation. This case is $4 \mathrm{~m}$ high. Thickness of the top stratum is $8 \mathrm{~m}$ and the cover thickness is $1 \mathrm{~m}$. If pile foundation runs through the karst cave to the bottom, its length will be higher than $24 \mathrm{~m}$. Due to the impact of the running casing in cast cave, it is easy to cause magma leakage to pollute groundwater. Hence, it is planned to place the bearing stratum of pile foundation in the karst roof. The safety of the roof-pile foundation system is determined according to calculation.

\section{Numerical Simulation of Pile Foundation System}

Simplification of Geological Model.In this study, the three-dimensional finite difference program FLAC $^{3 \mathrm{~d}}$ was used for analog computation. Height and width of this karst cave are about $4 \mathrm{~m}$ and $8 \mathrm{~m}$. The length is estimated $8 \mathrm{~m}$. It is highly developed. The upper boundary of the model is determined the ground line, and horizontal boundaries on two directions are five times of the corresponding karst length. The thickness from karst bottom surface to the lower edge is determined same with thickness of roof stratum. Therefore, the horizontal size and vertical size of the model are determined $48 \mathrm{~m}$ and $36 \mathrm{~m}$, respectively. The top surface and four sides of the model use fixed constraint and the top surface is free. Since this karst is stable under natural conditions, the roof stability is mainly determined by acting force of pile foundations. Hence, a pile unit model is constructed and pile loads are applied at the acting point of the upper boundary pile foundation. Value of this pile load is determined according to investigation report, which is $8000 \mathrm{kN}$. The Mohr-Coulomb model is chosen as the mechanical model. Loads are applied after the calculation equilibrium of natural gravity field.

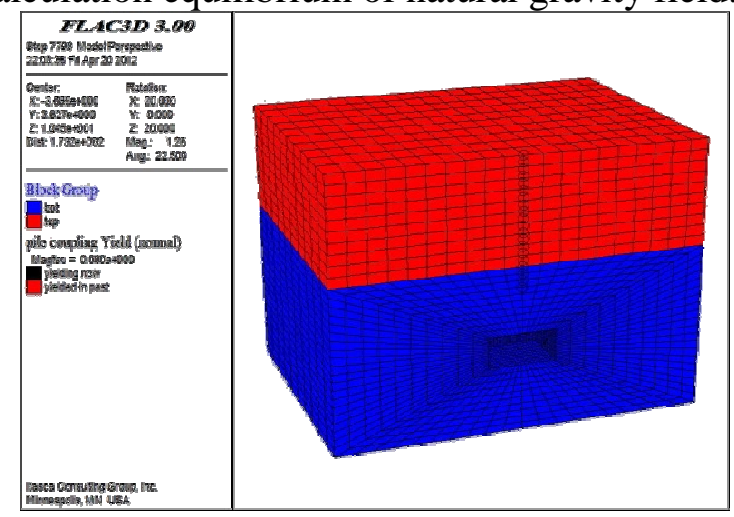

Fig.1 Cross-section of numerical model 
In analog computation of static force, parameters to calculate FLAC include density, gravitational acceleration, angle of internal friction, cohesive stress, modulus of elasticity and Poisson's ratio (Table 1 and Table 2).

Table 1 Calculated parameters of rock-soil layer

\begin{tabular}{cccccc}
\hline & $\begin{array}{c}\text { Bulk modulus } \\
(\mathrm{MPa})\end{array}$ & $\begin{array}{c}\text { Shear modulus } \\
(\mathrm{MPa})\end{array}$ & $\begin{array}{c}\text { Cohesive force }(\mathrm{kPa}) \\
\text { Silty clay }\end{array}$ & $\begin{array}{c}\text { Angle of internal friction } \\
\left({ }^{\circ}\right)\end{array}$ & $\begin{array}{c}\text { Gravity } \\
\left(\mathrm{MN} / \mathrm{m}^{3}\right)\end{array}$ \\
\hline Moderately weathered limestone & 22000 & 2.4 & 0.035 & 19.5 & 16 \\
\end{tabular}

Table 2 Values of calculation parameters of pile foundation

\begin{tabular}{ccccccc}
\hline $\begin{array}{c}\text { Pile } \\
\text { diameter } \\
(\mathrm{m})\end{array}$ & $\begin{array}{c}\text { Designed } \\
\text { load } \\
(\mathrm{kN})\end{array}$ & $\begin{array}{c}\text { Density } \\
(\mathrm{kg} / \mathrm{m} 3)\end{array}$ & $\begin{array}{c}\text { Modulus of } \\
\text { elasticity } \\
(\mathrm{GPa})\end{array}$ & $\begin{array}{c}\text { Poisson's } \\
\text { ratio }\end{array}$ & $\begin{array}{c}\text { Bulk } \\
\text { modulus } \\
(\mathrm{GPa})\end{array}$ & $\begin{array}{c}\text { Shear } \\
\text { modulus } \\
(\mathrm{GPa})\end{array}$ \\
\hline 1.2 & 8000 & 2500 & 25 & 0.2 & 13.9 & 10.4 \\
\hline
\end{tabular}

\section{Calculated results and analysis}

Analysis of Stress Results. The stress cloud map along the $\mathrm{z}$ direction is shown in Fig.2. In the silty clay blanket, stress distributes relatively uniformly and is influenced by karst cave slightly. In underlying rock mass which is far away from the karst cave, stress is influenced slightly by the karst cave, while stress close to the karst cave changes violently. The top surface and bottom surface of karst cave locate in free face and stress along the $\mathrm{z}$ direction is 0 . Stress increases gradually as distancing away from the karst cave and becomes immune to karst cave in far places.

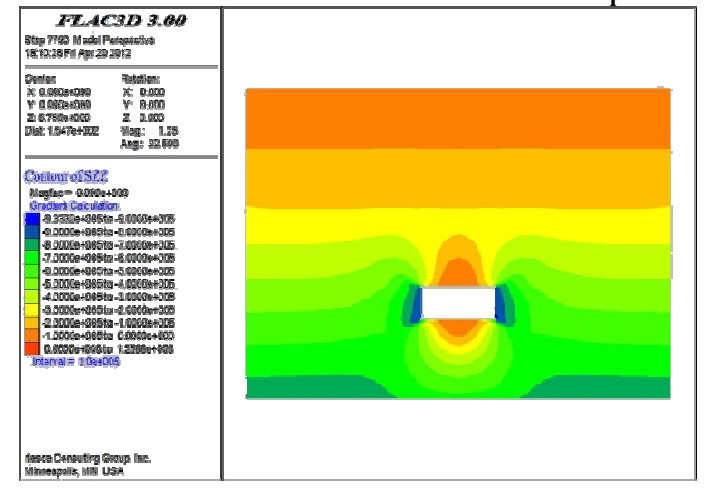

Fig.2 Stress cloud map on the vertical direction (SZZ)

Analysis of Displacement Results. Vertical displacement distribution is shown in Fig.3. Displacement in the pile foundation coverage is larger than that of other regions, forming an evident displacement loop structure. There's great deformation at karst cave top and deformation decreases gradually from the middle point of upper wall to the outward direction, indicating the serious downward bending deformation of karst roof. The bottom deformation of the karst cave increases gradually from the middle point of lower wall to the outward direction, indicating the serious arch deformation at bottom of karst cave. 


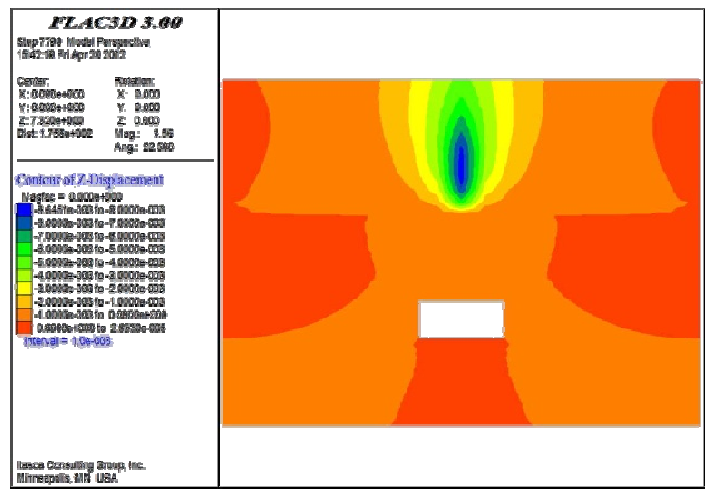

Fig.3 Displacement cloud map on the vertical direction

Deformation at Monitoring Points.To understand effect of pile foundation load, displacements at three points are monitored: point 1 (pile bottom), point 2 (karst roof) and point 3 (side wall of karst cave). Monitoring curves of these three points are shown in Fig.4, Fig.5 and Fig.6.

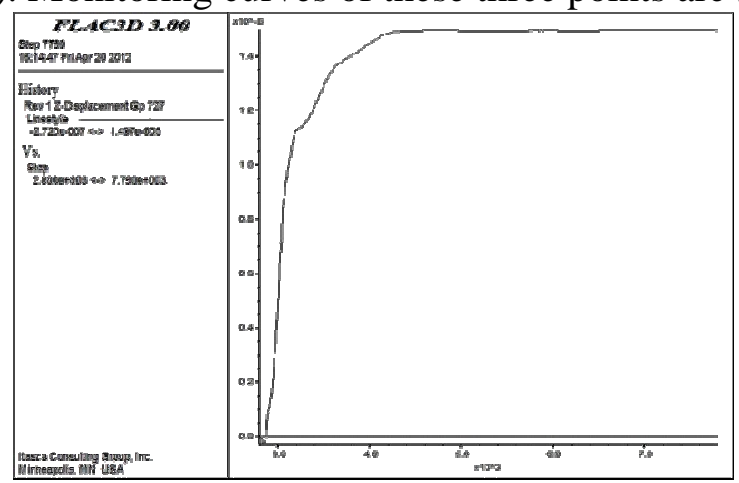

Fig.4 Settlement curves at point 1

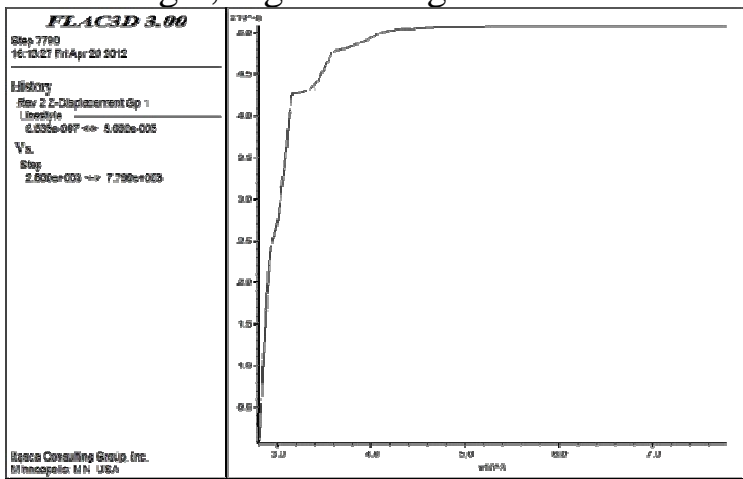

Fig.5 Settlement curves at point 2

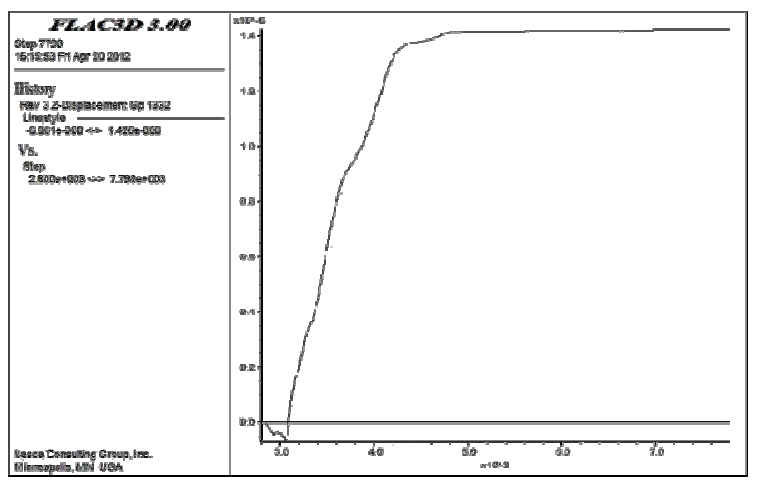

Fig.6 Displacement curves at point 3

Obviously, the pile bottom and karst roof generate great downward displacement due to the direct effect of pile foundation load. The side wall of karst cave is influenced by piles indirectly, thus generating small displacement toward the karst cave.

Analysis of Pile Function Effects Under Different Depths of Rock-Socketed.Monitoring curves of displacement at pile bottom, karst roof and side wall under different depths of rock-socketed are shown in Fig.7, Fig.8 and Fig.9. 


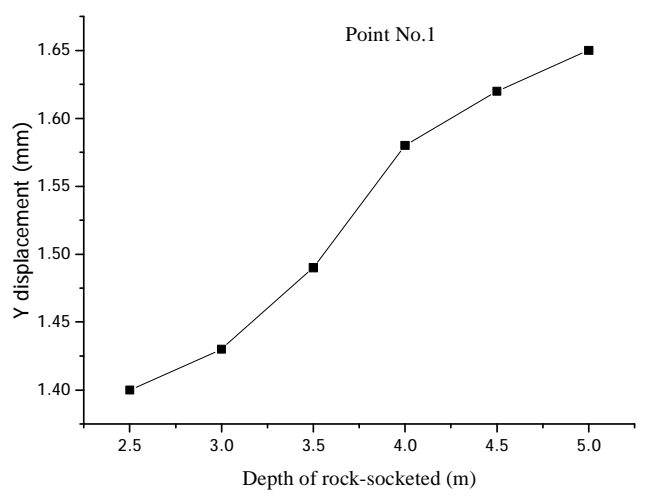

Fig.7 Displacement curve at pile bottom (1\#) under different depth of rock-socketed

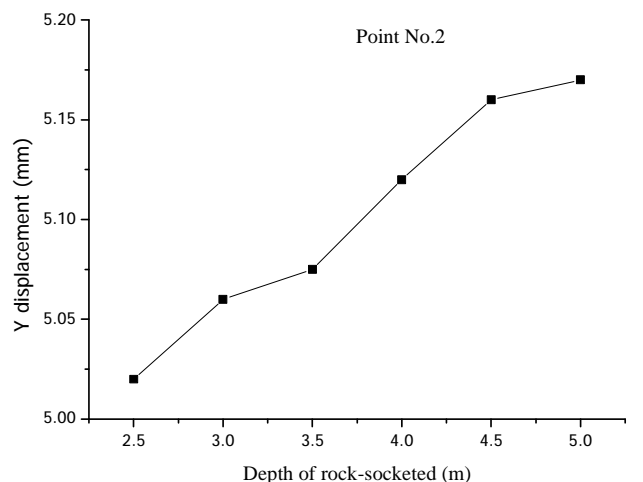

Fig.8 Displacement curve at karst roof (2\#) under different depth of rock-socketed

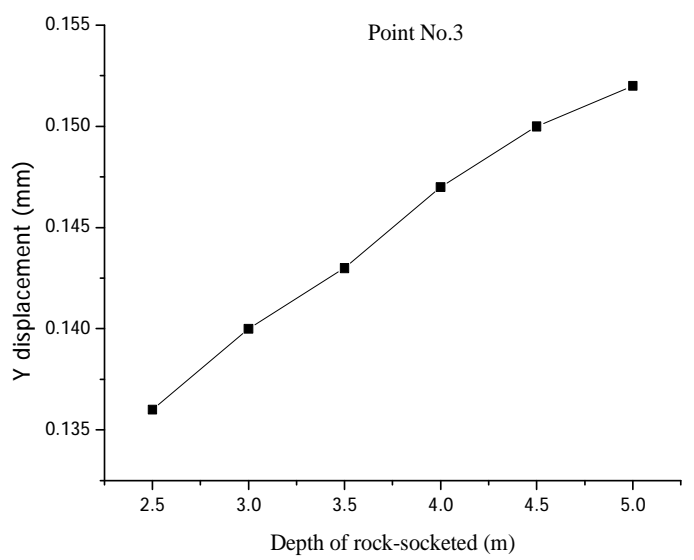

Fig.9 Displacement curve at side wall (3\#) under different depth of rock-socketed

Clearly, the depth of rock-socketed is positively correlated with karst deformation. The higher the depth of rock-socketed is, the smaller the distance to the karst roof and the smaller the roof supporting thickness will be, thus resulting in greater deformation.

\section{Conclusions}

A numerical simulation on karst cave under the pile foundation load for a power transmission tower in the study area is carried out by using the three-dimensional numerical simulation software FLAC3D. According to numerical calculation, the karst roof generates a large downward bending deformation under pile foundation load. The displacement cloud map of the whole roof-pile foundation system in the vertical range presents a rugby-shaped circle layer distribution pattern. The karst bottom generates large upward arch deformation. Besides, large tensile stress concentration regions are developed on the foundation and surrounding areas of the karst cave. Effects of depth of rock-socketed on the system displacement are discussed. It finds that depth of rock-socketed is positively related with karst deformation. The higher the depth of rock-socketed is, the smaller the distance to the karst roof and the smaller the roof supporting thickness will be, thus resulting in greater deformation. Research conclusions can offer certain references to design, construction and operation monitoring of the project, as well as some references for similar engineering constructions. 


\section{Reference}

[1] Ahmed Tahaa, M. Hesham El Naggarb,n, Alper Turanc. Numerical modeling of the dynamic lateral behavior of geosynthetics-reinforced pile foundation system. Soil Dynamics and Earthquake Engineering.2015, 77:254-266.

[2] Junyoung Ko, Jaeyeon Cho, Sangseom Jeong. Nonlinear 3D interactive analysis of superstructure and piled raft foundation. Engineering Structures.2017,143:204-218.

[3] Paravita Sri Wulandari, Daniel Tjandra. Analysis of piled raft foundation on soft soil using PLAXIS 2D. Procedia Engineering. 2015, 125:363 - 367.

[4] A.Z. Elwakil, W.R. Azzam. Experimental and numerical study of piled raft system. Alexandria Engineering Journal. 2016 55: 547-560.

[5] Kheradi Hamayoon, Yukihiro Morikawa, Ryosuke Oka,et.al. 3D dynamic finite element analyses and $1 \mathrm{~g}$ shaking table tests on seismic performance of existing group-pile foundation in partially improved grounds under dry condition. Soil Dynamics and Earthquake Engineering. 2016,90: 196-210.

[6] Zihao Zhao, George Kouretzis, Scott Sloan, et.al. Ultimate lateral resistance of tripod pile foundation in clay. Computers and Geotechnics. 2017,92:220-228(In Chinese).

[7] Kazimierz Józefiak, Artur Zbiciak, Maciej MaĞlakowski, et.al. Numerical modelling and bearing capacity analysisof pile foundation. Procedia Engineering. 2015,111:356 - 363.

[8] Xuezhang Wen, Fangyuan Zhou, Nobuo Fukuwa, et.al. A simplified method for impedance and foundation input motion of a foundation supported by pile groups and its application. Computers and Geotechnics. 2015,69:301-319(In Chinese).

[9] Aijun Yao, Jiantao Zhang, Yijun Zhou. Study on the dynamic response of the steel pipe pile foundation during construction of neighborhood deep excavation. Procedia Engineering. 2016, 165:58 - 68(In Chinese).

[10] Mahmoud N. Hussien, Tetsuo Tobita, Susumu Iai, et.al. On the influence of vertical loads on the lateral response of pile foundation. Computers and Geotechnics. 2014,55:392-403.

[11] Jingrui Niu, Ibrahim A. Oyediran, Daan Liu, et.al. Quantitative foundation stability evaluation of urban karst area: Case study of Tangshan, China. Soils and Foundations. 2015;55(3):493-503. 